\title{
Who are the most inclined to learn? Evidence from Chinese multinationals' internationalization in the European Union
}

\author{
Liang Chen ${ }^{1}$ (D) Yi Li ${ }^{2} \cdot \mathrm{Di} \mathrm{Fan}^{3}$
}

Published online: 28 June 2019

(C) The Author(s) 2019

\begin{abstract}
While it is widely recognised that an asset-augmenting rather than assetexploiting strategy drives emerging multinationals' (EMNEs) internationalization, current research focuses on the motivations behind knowledge seeking FDI. What remains less clear is why latecomer firms can engage in learning in advanced countries. Conjoining the "Linkage-Leverage-Learning (LLL)" framework and knowledge seeking literature, this study shows how Chinese investment in the European Union reveals the preconditions for foreign knowledge sourcing. We follow a set-theoretic approach, utilizing fuzzy-set qualitative comparative analysis (fsQCA), to identify equifinal configurations of linkage and leverage conditions leading to high learning propensity of EMNEs. Our analysis extends the LLL framework and complements the recent debate on the theory of the EMNE. We develop propositions based on distinct constellations of learning antecedents.
\end{abstract}

Liang Chen, Yi Li and Di Fan contributed equally to this work.

Electronic supplementary material The online version of this article (https://doi.org/10.1007/s10490-0189605-9) contains supplementary material, which is available to authorized users.

Liang Chen

liang.chen@unimelb.edu.au

Yi Li

yi.li2@sydney.edu.au

Di Fan

david.fan@uwa.edu.au

1 Department of Management and Marketing, University of Melbourne, Parkville, Australia

2 Discipline of International Business, University of Sydney, Sydney, Australia

3 Management and Organisations (UWA Business School), University of Western Australia, Perth, Australia 
Keywords Linkage-leverage-learning (LLL) · China - EU · Emerging multinationals · Fuzzy-set qualitative comparative analysis (fsQCA)

Over the past decade, the growth of multinationals from emerging countries (EMNEs) has challenged the conventional IB theory. Success in advanced markets typically requires sophisticated products and services, which most EMNEs are yet to offer due to the lack of intangible-based advantages (Hennart, 2012). Researchers thus focus the explanatory lens on the strategic intent of EMNEs (Rui \& Yip, 2008), whose investments in developed countries are arguably driven by the acquisition of intangible assets - an "asset-augmenting" rather than "asset-exploiting" strategy (Dunning, 2000) - in order to reinforce their leadership in the home market and enhance competitiveness on the global stage (Luo \& Wang, 2012). While alternative theoretical frameworks proposed have yielded numerous insights into the motivations and processes of this strategy (Kedia, Gaffney, \& Clampit, 2012; Luo \& Tung, 2007; Mathews, 2006), a key research question remains underexplored: what allows for EMNEs' asset-augmenting strategy?

This paper builds upon the "Linkage-Leverage-Learning" (LLL) framework to examine the preconditions for EMNEs' knowledge sourcing in advanced markets. LLL provides an insightful account of the process by which latecomer MNEs engage in asset-augmenting activities and catch up with the incumbents (Mathews, 2002, 2006). By linking with advanced country firms and leveraging cumulative resources, EMNEs can access and source knowledge from advanced countries and develop proprietary capabilities. While LLL bears close relation to EMNEs' internationalisation by explaining how firms create rather than sustain ownership advantages (Mathews, 2002), it is rather silent on one important phenomenon; the heterogeneous nature of contemporary EMNEs suggests that not all firms are equally poised to implement this asset-augmenting strategy (Hennart, 2012). Given that LLL is a framework of strategic choice, we make two assumptions - informed by knowledge seeking research - to extend LLL and fill this gap in the literature. First, we assume that location choices are endogenous to knowledge sourcing. Locating value-adding activities in countries with a greater stock of technological knowledge comes at a price, i.e. higher factor costs and greater competition. EMNEs willing to accommodate this price show a stronger learning propensity than those investing in a low knowledge country (Jaffe, Trajtenberg, \& Henderson, 1993). Second, we postulate that firms proactively make this decision depending on environmental conditions and resource constraints (Alcácer \& Chung, 2007).

The study draws upon the set-theoretic approach and fuzzy-set qualitative comparative analysis (fsQCA), which allows for "configurational classifications and judgements based on the simultaneous consideration of multiple interdependent factors" (Campbell, Sirmon, \& Schijven, 2016, p.169). Our analysis reveals how equifinal configurations of individual "linkage" and "leverage" conditions lead to strong learning propensities of Chinese MNEs in the European Union (EU). The diversity of knowledge stock and factor cost across the member states makes the EU an ideal context for our inquiry. The EU single market would allow market-seeking or efficiency-seeking FDI to take advantage of low factor cost locations and eschew knowledge-rich member states for efficiency reasons, such that locating in different EU member states implies whether the investment has a knowledgeseeking purpose. Like all set-theoretic approaches, fsQCA fits a unique middle ground between qualitative and quantitative methods, and is based on the idea that causal 
relationships can be better understood in terms of set-theoretic relations rather than correlations (Fiss, 2007, 2011; Ragin, 2008). Following an abductive and theory-building process, we develop a mid-range theory (Crilly, 2011), to deepen our understanding of EMNEs' learning propensity.

Our study contributes to the theory of the EMNE. Our basic premise is that EMNEs do not need to possess intangible-based ownership advantages ex ante for foreign expansion (Hashai \& Buckley, 2014). We follow Hennart's (2012) account as to how market imperfections of the emerging economies confer sufficient rent generation and appropriation opportunities on domestic firms, who can then finance knowledgeseeking FDI and withstand short-term performance distress abroad. This general condition makes possible EMNEs' emergence. Yet not all EMNEs seek to acquire knowledge in advanced markets (Narula, 2012); nor do acquiring production knowledge and catching up on output capabilities require physical presence at knowledge centres (Awate, Larsen, \& Mudambi, 2012). For those striving to develop sustainable advantages and the "next generation" of the product, knowledge-seeking FDI seems the most effective means to access a broader range of core and complementary technologies necessary for catch-up (Brusoni, Prencipe, \& Pavitt, 2001). This means, nevertheless, is not equally available to all. By showing what allows EMNEs to venture abroad in search of valuable technologies, we identify the preconditions for the development of EMNEs' sustainable competitive advantages and their long-term success. Our research thus adds onto the debate on the necessity of ownership advantages for the emergence of the multinational enterprise - the fundamental but most puzzling theoretical question in the EMNE literature (Cuervo-Cazurra, 2012; Hennart, 2012; Narula, 2012; Ramamurti, 2012). Building on the knowledge seeking research (Alcácer \& Chung, 2007; Chung \& Alcacer, 2002; Chung \& Yeaple, 2008), we provide a more general account to complement the LLL framework's predisposition toward international partnership and crossborder acquisition as a means to acquire intangible assets (Mathews, 2006).

Our distinctive methods also yield fresh insights into latecomers' multiple pathways toward learning. Previous studies of Chinese MNEs' catch-up tend to restrict the analytical lens to a selected group of champion firms, notably Lenovo, TCL and Haier (Deng, 2009; Li, 2007; Rui \& Yip, 2008). We move beyond descriptive accounts of these champions, and employ a more structured approach to identify characteristics of a range of Chinese latecomers. While regression studies are inherently interested in independent effects and tend to isolate variables with the greatest explanatory power, e.g. the more absorptive capacity the better the chance of learning, we argue that incorporating causal complexity and complementarity of linkage and leverage conditions extends the LLL framework and the current understanding of EMNEs' internationalization. Viewing latecomer learners as distinct groups of firms instead of a homogenous lump also has important policy implications.

\section{Emerging multinationals' catch-up - Linkage, leverage and learning}

\section{EMNEs and the LLL framework}

The rapid growth of EMNEs, especially those from China, has puzzled IB researchers. The conventional ownership-location-internalisation (OLI) paradigm suggests that 
ownership advantages, in terms of technological capability, management know-how and other intangible assets, are necessary for cross-border expansion, and they serve to offset MNEs' liability of foreignness, making the investment economically viable (Dunning \& Lundan, 2008). Conversely, EMNEs' advantages in the home country primarily revolve around cost leadership, political connections and distribution system, and fit well the least developed markets (Garcia-Canal \& Guillén, 2008); but they are hardly transferrable to advanced countries, and, even if temporarily feasible, cannot sustain their advantage over local rivals or incumbent firms (Narula, 2012). A prominent explanatory framework to extend the received theory is proposed by Mathews (2002, 2006), who focuses on resource-poor EMNEs' accelerated internationalisation through the distinct lens of LLL. The basic premise is that EMNEs are often latecomers to the industry where they compete, and their foreign expansion is driven by the intention to catch up with the established firms from developed country in terms of competitiveness on a global level. Such catch-up is the outcome of continuous learning, which is facilitated by "linkage" and "leverage" factors.

Linkage refers to the outward-oriented connections that EMNEs possess or explore in order to tap into sources of new knowledge and generate learning opportunities (Mathews, 2002, 2006). Whether linkages with incumbent knowledge holders in a foreign country can be established may depend on the ease with which to break into the existing network, the bridging mechanism through a third-party intermediary, and/or the availability of "boundary-spanners" within the EMNE. Leverage refers to EMNEs' capacity to secure resources from these linkages (Mathews, 2002). This is not to suggest that ownership advantage and advantageous competitive position are prerequisites for foreign investment (Hashai \& Buckley, 2014). Instead, to realise learning potential of the external linkages, latecomers only need to possess at least some firmspecific assets beyond a threshold level, or some comparative advantages (e.g. financial resources) idiosyncratic to their home country (Narula, 2012). Although external linkages confer access to new knowledge and skills that can enhance firms' competitiveness, firms do not benefit equally from these linkages or have the same capacity to take advantage of them. Leverage conditions facilitate firms' reaching out to the resources in advanced markets, and represent their complementary resources and organisational capabilities to make use of foreign knowledge. Finally, the outcome of repeated applications of resource leveraging by means of linkage is described as learning. Linkage with the value chain opens up learning possibility, and the capacity to leverage ensures the fruitfulness of tapping external linkages. It is perfectly possible for a firm to have either linkage or the capacity to leverage, but neither alone is sufficient for learning. Only the mutual presence of linkage and leverage can unleash the potential of catch-up opportunities and allow latecomers to learn how to become globally competitive.

\section{Foreign knowledge sourcing and learning propensity}

The LLL framework focuses primarily on the descriptive process of catch-up (Tan \& Mathews, 2015), whilst saying little about what exact behaviour is reflective of learning. Knowledge seeking literature suggests that learning is a latent process of combining knowledge from fields of expertise previously unfamiliar to the MNE with existing knowledge in attempts to create performance-enhancing competence (Kogut \& 
Zander, 1993). Due to spatial boundedness of knowledge diffusion and localised spillovers, new knowledge is best accessed at the place of origin (Jaffe et al., 1993), and the benefits from spillovers decline with distance (Cantwell \& Piscitello, 2005). Physical proximity is particularly important because transferring tacit knowledge requires frequent interpersonal contacts (Kogut \& Zander, 1992). For latecomers, foreign investment provides the effective means by which to access technological knowledge abroad, in order to close the gap with the leaders or reduce internal fixed innovation costs (Chung \& Yeaple, 2008). As opposed to incumbents' superior endowment of firm-specific assets, latecomers' ownership advantages are endogenously created - by buying equity in existing firms or establishing greenfield subsidiaries - in knowledge-rich locations where agglomeration economies permit learning (Hennart, 2012; Jindra, Hassan, \& Cantner, 2016; Li, Li, \& Shapiro, 2012). "Common buyers and suppliers, chance meetings of different firms' scientists and engineers, and employees switching jobs" constitute important channels for acquiring external knowledge (Alcácer \& Chung, 2007, p. 760).

Drawing on knowledge seeking literature, we can argue for two basic premises for examining EMNEs' catch-up. First, foreign locations offer differentiated potential of learning owing to heterogeneous geographic distribution of knowledge-generating activities (Cantwell, 2009) and to the positive correlation between knowledge stock and the extent of localised spillovers (Cantwell \& Mudambi, 2011). Second, location strategies of EMNEs reflect their propensity to take advantage of spatially specific knowledge, and, ultimately, to learn to develop sophisticated innovation capabilities (Chung \& Alcacer, 2002; Jindra et al., 2016). This applies to both full or partial acquisitions and greenfield investments (Hennart, 2012; Li et al., 2012). These are reasonable premises, given the growing consensus that EMNEs' investment in advanced markets is primarily driven by an intent to acquire knowledge from technologically more competent counterparts and the associated value chains ( $\mathrm{Li}$ et al., 2012; Lyles, Li, \& Yan, 2014). A more crucial point is that knowledge-rich locations may be the result of stronger firm competition (Chung \& Yeaple, 2008) or location-specific endowment (Narula, 2012), neither of which provides a competitive, efficient factor market for economic activities other than knowledge sourcing, such as import substitution.

While it is recognised that MNEs' strategic orientation toward exploration vis-à-vis exploitation motivates their engagement in knowledge-seeking FDI (Kedia et al., 2012), less noted is that firms are not equally equipped to access and acquire new knowledge, even if they are highly motivated to do so. Nor are they able to initiate knowledge-seeking FDI at will, due to resource constraints (Hennart, 2012). A critical question remains unanswered as to what external and internal conditions enable EMNEs' learning. In this study, we focus specifically on EMNEs' propensities to source knowledge. Sourcing knowledge does not necessarily lead to successful learning in terms of increased productivity or innovation capabilities (Ray, Ray, \& Kumar, 2017; Tian, 2017). That said, it remains critical because understanding the preconditions for learning not only contributes to the alternative, asset-augmenting theory of FDI, but also helps clarify whether and how EMNEs can create firm-specific advantages and sustain in global markets - the central inquiry in the studies of the EMNE.

LLL provides the overarching theoretical framework to address our research question. We thus refer linkage to conditions that facilitate the establishment of network ties 
with knowledge holders in the knowledge centre, and refer leverage to resource- and capability-based conditions needed to carry out knowledge-seeking FDI. These conditions may work complementarily or substitutively. The remainder of the paper employs a structured approach to explore how the combinations of linkage and leverage conditions lead to high learning propensities of EMNEs as reflected by their location strategies.

\section{Methods}

\section{Sample and data}

Our sampling frame consists of all Chinese-listed manufacturing firms over 2010 2012. As previously shown, Chinese firms invest increasingly in developed economies with the strategic intent of catch-up (Cui, Meyer, \& Hu, 2014; Rui \& Yip, 2008). Investment by this sample of firms in the EU was rare before 2010. We extracted those that had established new subsidiaries in the $27 \mathrm{EU}$ member states ${ }^{1}$ between 2010 and 2012. BvD Osiris and Wind databases, alongside annual reports, provided information about firms' foreign subsidiaries. To avoid dependence between observations, we ensured that the firm had not invested in the same country for five years prior to the focal investment, and eliminated subsequent entries by the same firm in the same country within the sampling period (Alcácer \& Chung, 2007). Given our focus on firms' learning propensity, we use firm-investment year as the unit of analysis. We obtained 57 observations, which also represent 57 different firms in this sample. Since a firm may invest in more than one EU member state in a year, our total data points amount to 76. Table 1 presents the country and industry distributions of the sample. All linkage and leverage variables are lagged by one year.

\section{Analytical approach}

This study employs a "middle-way" research design between a purely deductive variable-oriented design and a purely inductive case-based design. A qualitative comparative analysis is best suited for this type of research as a synthetic strategy that integrates the strengths of variable- and case-based approaches (Ragin, 2008). We explore our research question following a configurational approach, utilizing the technique of fsQCA. Grounded in set theory, fsQCA is an analytic technique presenting each case (i.e. each firm in our sample) (Crilly, 2011; Fiss, 2007, 2011; Ragin, 2008). It models conjunctural causation, i.e., the idea that configurations of various conditions collectively, rather than one condition alone, relate to the outcome in question (Judge, Fainshmidt, \& Brown, 2014; Schneider, Schulze-Bentrop, \& Paunescu, 2010). This fits well our LLL-based framework, where we argue that linkage and leverage conditions combine to lead to high learning propensity. Moreover, multiple causal pathways can be detected by fsQCA, providing more than one possible combination of causal conditions that can be linked to the same outcome. In other words, the fsQCA approach captures potential equifinality, a situation where "a system can reach the same final

\footnotetext{
${ }^{1}$ Croatia did not join the EU until 2013.
} 
Table 1 Distribution of sampled Chinese investments in the EU, 2010-2012

a) Frequency of entry by host country

FDI destinations in the EU

Frequency of entry by host country

Austria

1

Belgium

3

Czech Republic 1

Denmark 3

France $\quad 2$

Germany 25

Hungary $\quad 3$

Italy 11

Luxemburg $\quad 3$

Malta 1

$\begin{array}{ll}\text { Netherlands } & 12\end{array}$

Poland 2

Romania 3

Spain $\quad 2$

Sweden 1

United Kingdom 3

Total 76*

*Setting up multiple subsidiaries by the same firm in the same country and year counts as one entry. A firm may enter multiple countries in a given year, and thus the total number 76 exceeds the number of firm observations.

b) Distribution of the sampled firms by industry*

$\begin{array}{ll}\text { Industry } & \text { Number of firms with new FDI } \\ \text { Manufacture of basic metals } & 3 \\ \text { Manufacture of chemicals and chemical products } & 4 \\ \text { Manufacture of computer, electronic and optical products } & 17 \\ \text { Manufacture of electrical equipment } & 8 \\ \text { Manufacture of fabricated metal products } & 1 \\ \text { Manufacture of leather and related products } & 1 \\ \text { Manufacture of macinery and equipment } & 13 \\ \text { Manufacture of motor vehicles, tailers and semi-trailers } & 8 \\ \text { Manufacture of other transport equipment } & 1 \\ \text { Manufacture of textiles } & 1 \\ \text { Total } & 57^{\wedge}\end{array}$

*Industry classification follows NACE Rev.2 by which country-level patent appilications (dependent variable) are sorted in Eurostat

^Including six firms with new FDI in 2010, 16 in 2011, and 35 in 2012

state from different initial conditions and by a variety of different paths" (Fiss, 2007, p. 1181). Although equifinality is not explicitly theorised by the LLL framework, we explore this possibility in our analysis. This is based on a reasonable premise that EMNEs showing great learning propensity should not be homogeneous. While fsQCA 
can operate with any number of cases, Fiss (2007, p. 1194) suggests that fsQCA is ideal for "allowing the analysis of small-N situations - that is, situations where the number of cases is too large for traditional qualitative analysis and too small for many conventional statistical analysis (e.g. between ten and fifty cases)". Therefore, fsQCA is both well-positioned to address the research question and suitable for our sample.

\section{Measures and calibration}

Calibration is one of the most important steps in applying a fuzzy-set approach. Although calibration is relatively new to social scientists, it has been a common practice among natural scientists, who calibrate measuring devices and adjust the readings that these devices produce so that they can match or compare them with dependably known standards. These standards make measurements directly interpretable. Ragin (2008) argues that the uniqueness of using calibration in a fuzzyset approach offers a middle path between quantitative and qualitative measurement. Calibration adopts the merit of precision from quantitative research in the form of transforming variables into sets that require the specification of full membership in a set of interests, full non-membership, and a crossover point of maximum ambiguity regarding membership. On the other hand, calibrating a variable requires qualitative judgment basing thresholds on meaningful external benchmarks.

In this study, we adopted the direct method of calibration introduced by Ragin (2008), one commonly used in fuzzy-set studies (e.g., Fiss, 2011; Schneider et al., 2010). The underlying rationale for this three-value fuzzy-set calibration is that the method rescales an interval-ratio variable using the crossover point as an anchor from which deviation scores are calculated, taking the values of full non-membership and full membership as the lower and upper bounds (Fiss, 2011). In practice, we assigned set membership scores with the calibration computing function in the fsQCA 2.5 software, which applies the log-odds method described in Ragin (2008). The embedded computing function produces a fine-grained calibration of the degree of set membership of cases, with scores ranging from .00 to 1.00 . The anchor points used for calibrating set membership scores are reported in Table 2.

\section{Outcome - Learning propensity}

We define the outcome as learning propensity. As argued earlier, EMNEs' location choice reflects their tendency to learn vis-à-vis market-seeking or efficiency-seeking motivations (Chung \& Yeaple, 2008). Higher levels of knowledge-generating activity and the resulting knowledge stock increase the likelihood and amount of spillovers (Alcácer \& Chung, 2007). Meanwhile, knowledge centres are typically associated with intense competition and a costly factor market due to agglomeration economy. Therefore, firms investing in a country with a greater knowledge stock and willing to assume such costs shows a higher learning propensity than those investing in a relatively low knowledge country. This applies particularly to the EU context where firms of other investment motivations can access the single market or cost-efficient assets without locating in knowledge intense, expensive countries.

We measure learning propensity using the relative knowledge stock of the host country. Given the whole host of knowledge available in foreign countries, we use two 


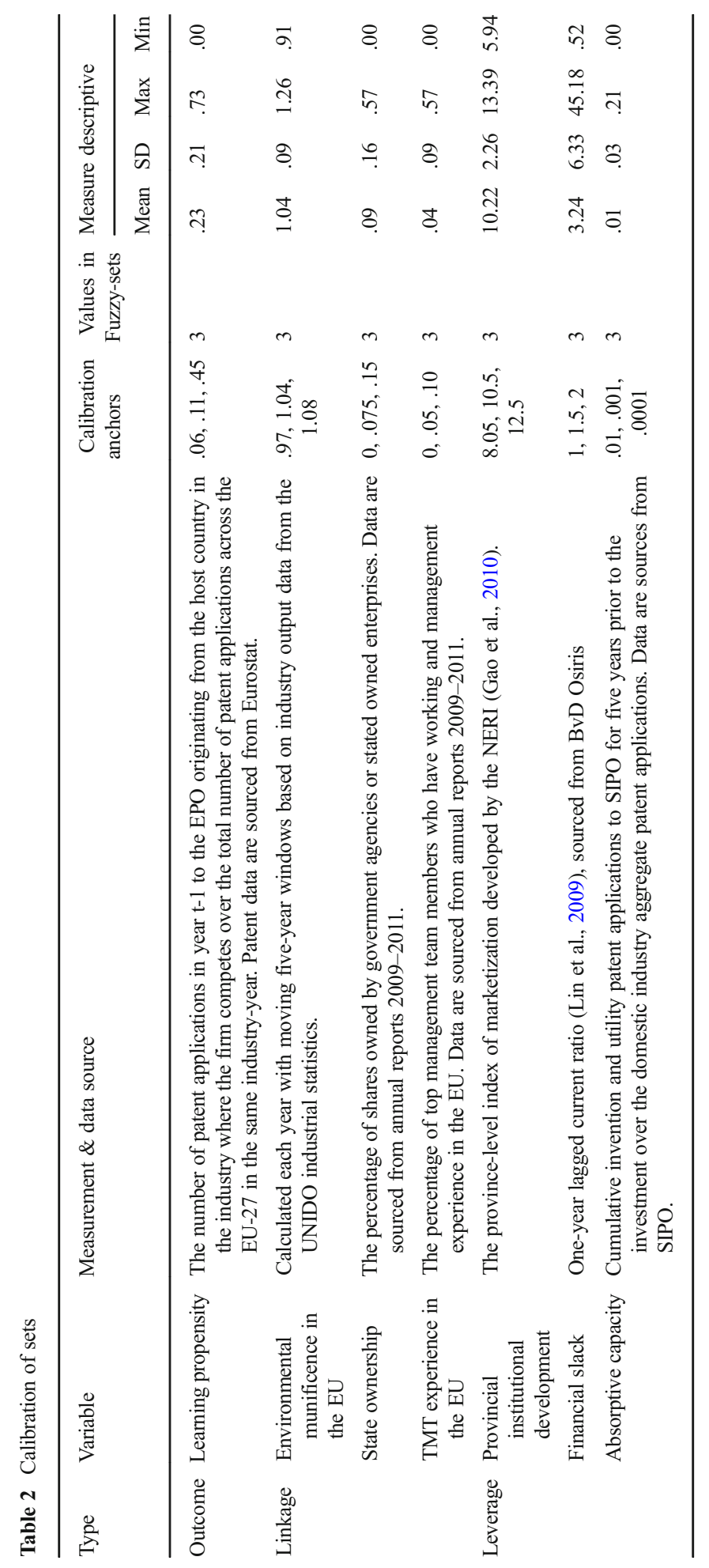


criteria to set the focus. First, we account for the stock of technological knowledge, since technology has been the primary target by knowledge-seeking FDI (Chung \& Alcacer, 2002). New technologies can be used not only to refine the existing product offerings and serve the current customer base better, but also to pave the ground for new product innovation that leads to market expansion and sustained growth. In our context, the country-specific advantages (CSA) argument suggests that Chinese FDI "reveal a search for the technology, management, and strategy skills missing in Chinese firms" (Rugman, 2009, p. 53). The consensus is that Chinese firms are particularly lagging behind Western firms in technology, and Chinese FDI in advanced markets is mostly motivated by technological catch-up (Li et al., 2012; Luo \& Tung, 2007).

Second, we focus on the stock of similar knowledge. Research suggests that knowledge-seeking FDI serves to reduce fixed innovation costs by combining the internal R\&D efforts with knowledge sourced externally (Chung \& Yeaple, 2008). The tacitness of technological knowledge makes it difficult to appreciate unrelated fields of endeavour and more costly to assimilate them with the current knowledge base (Cantwell \& Mudambi, 2011). Firms are thus inclined to access complementary external knowledge close to their own, which supposedly resides in the same industry (Li et al., 2012). Different advanced countries enjoy technological advantages in different industries (Cantwell \& Janne, 1999). Therefore, we measure a firm's learning propensity for year $\mathrm{t}$ by the total number of patent applications in year $\mathrm{t}-1$ to the European Patent Office that originated from the host country in the industry where the firm competes over the total number of patent applications across the EU-27 in the same industry-year. Patent counts were retrieved from Eurostat and reflect applications by host country residents. In cases where a firm invests in multiple EU member states in a given year, we aggregate patent counts from all host countries as the numerator. The higher the ratio, the greater the stock of technological knowledge and amount of spillovers in the host country vis-à-vis other EU countries regarding a given industry. Hence our measure considers firm-, country- and industry-specific characteristics.

Our study takes advantage of the EU common market context in identifying learning propensity; the higher the measure, the more likely the firm is to access new knowledge vis-à-vis to serve the EU market from a single manufacturing or distribution facility or to evade tax. To incorporate this between-firm comparison in our sample, we calibrated learning propensity by the 25 th- 50 th- 75 th percentile approach following the best practice of fuzzy-set analysis (Ragin, 2008; Fiss, 2011). The fully-in membership in the set of FDI learning propensity was coded 1 if the ratio is higher than $45 \%$ and above (i.e., about the 75 th percentile), which suggests that the focal subsidiary shows strong learning propensity by locating in a given host country (such as Chinese firm's FDI in Germany or United Kingdom). The fully-out membership in the set was coded 0 if the ratio is equal or lower than $6 \%$ (i.e., about the 25th percentile), which suggests that the focal subsidiary displays weak learning propensity (such as Chinese firm's FDI in Romania or Luxemburg). The crossover point was set at the 50th percentile (11\%), which implies the most ambiguous purpose for Chinese MNE's FDI. With fuzzy-set method, we can analyse combinations of causal factors leading to fully-out membership of outcome, which are used to predict configurations of linkage and leverage factors leading to strong learning propensity FDI. Thus, observations regarding weak learning propensity are not noise but valuable data for fuzzy-set analysis. 


\section{Linkage conditions}

We identify three linkage conditions. Environmental munificence denotes the ease of connecting with local actors as shaped by the host-region environment. State ownership reflects the extent to which the firm can capitalise on home-country political support and diplomatic linkages in establishing network ties. TMT experience in the EU points to the firm-specific means by which to build local connections at the knowledge centre. These three linkage conditions may work independently, complementarily or substitutively.

Environmental munificence To access complementary knowledge at foreign knowledge centres, the EMNE needs to establish network linkages with local knowledge holders, such as customers, suppliers and competitors, by embedding itself in the supply chain and production network (Andersson \& Forsgren, 2000). This is because some types of knowledge are exclusive to network insiders (Cantwell, 2009). Network linkages increase the frequency and intensity of information exchange, and help the EMNE recruit experienced personnel from competitors (Chung \& Yeaple, 2008; Li et al., 2012). For example, the EMNE's subsidiary may produce equipment used in the customer's production and work closely with the customer to develop a refined component to be installed in that equipment. The subsidiary can then achieve reverse knowledge transfer by supplying this new component to other subsidiaries of the EMNE around the globe (Andersson \& Forsgren, 2000). Embedding in the production network also allows latecomers to search more widely local specialised knowledge that can be combined to serve their own purposes (Cantwell \& Mudambi, 2011). Nevertheless, the ease with which to connect with local actors depends on the task environment (Cantwell \& Mudambi, 2005). At industry level, a munificent environment features abundant resources and capacity to support sustained growth (Dess \& Beard, 1984). Chung and Alcacer (2002) also emphasized that abundant and matching industrial resources can influence location choice of firm's knowledge-seeking FDI. Abundant resources attenuate competition intensity and support firms in pursuing goals other than survival (Castrogiovanni, 1991). This increases the tendency for new firms to enter this market and share those productive resources. In a less munificent environment, suppliers and distributors will be contractually tied to incumbent manufacturers or owned by them. Limited growth in the industry implies that it is difficult to reshape the production ties and break into the established network. The lack of resources and intense competition also induce incumbent competitors to protect actively their knowledge base by limiting the extent of interorganisational cooperation, restricting employee mobility and tightening relations with suppliers, all of which make knowledge exchange difficult (Chung \& Yeaple, 2008).

Environmental munificence is calculated each year based on moving five-year window data sourced from the United Nations Industrial Development Organization (UNIDO) industrial statistics database. To measure environmental munificence at industry-level, we followed the method of strategic management scholars (Fernhaber \& Patel, 2012; Keats \& Hitt, 1988), and regressed a natural logarithm of industry outputs on time and took the anti-log of beta as the measure, which represents the average industry growth rate over the five-year moving window. In calibration, the 25th-50th-75th percentile approach was applied (Fiss, 2011). Industries with values 
below .97 (i.e., about the 25th percentile) are coded as entirely out of the set of munificent environment. The crossover value is set at 1.035 (i.e., about the 50th percentile), while industries with values above 1.075 (i.e., about the 75 th percentile) are coded as entirely in the set of munificent environment.

State ownership It has been argued that industrial catch-up is initiated by firms, in conjunction with support from the government (Mathews, 2002). The consensus is that Chinese firms benefit from state backing when venturing abroad (Li, 2007), and stateowned EMNEs may receive governmental support for knowledge-seeking activities (Li et al., 2012; Luo \& Tung, 2007). While state influence can take different forms, the government exerts direct control through ownership arrangements (Wang, Hong, Kafouros, \& Wright, 2012). State ownership creates "a political linkage between a firm and its home country institutions that allows the firm to be resource dependent on the home institutions" (Cui \& Jiang, 2012, p. 265). Conventional understanding points to the state-owned enterprises' (SOEs') privileged access to financial underwriting (Luo, Xue, \& Han, 2010) and low-interest loans provided by state-owned banks (Luo \& Tung, 2007). However, state ownership may give rise to ideological conflicts and be associated with unfair competitive advantage, leading to reduced legitimacy in advanced countries (Meyer, Ding, Li, \& Zhang, 2014). We argue that, in the case of foreign knowledge sourcing, a third mechanism prevails. That is, stronger political connections allow SOEs to capitalise on the home government's diplomatic support to access foreign knowledge centres. The Chinese government conveys its intention to encourage and support trade and investment relations with a foreign country by means of high-level government visits, which are typically accompanied by top executives of SOEs. The choice of country for reinforcing diplomatic ties is conditional on cues from the host country and by the home state's overall strategic interests (Kinne, 2014). One of these is industrial catch-up. By introducing domestic SOE executives to advanced country political and business leaders, the Chinese government aims to alleviate informational uncertainty around the SOE as perceived by local stakeholders, and to connect the SOE with the dominant actors in the industry and their production networks. We measure state ownership by the percentage of shares owned by government agencies or SOEs, using data from their annual reports. Following Fiss (2011), we calibrated state ownership by the adjusted 25 th-50th-75th percentile approach. The fully-in membership in the set of state ownership was coded 1 if the ratio is higher (15\% and above, i.e., about the 75th percentile) and was coded 0 if the ratio is equal to $0 \%$. The crossover point was set at $7.5 \%$ (that is, an average point between fully-in and fully out membership thresholds).

Top management team (TMT) experience in the EU To access knowledge in a foreign country, the EMNE must know of its existence, location, characteristics, whom to contact and how to connect with the knowledge holder. All of the information may involve significant search cost. A diplomatic channel is not necessarily the only viable route. The firm can recruit experienced personnel into the TMT or capitalise on existing TMT members who have experience in the host region. In general, TMT international experience reduces informational uncertainty and has a promoting effect on the firm's internationalisation (Sambharya, 1996). In the case of knowledge sourcing, TMT experience in the host region through education or career tenure plays a "boundary- 
spanning" role between the firm and the host country. It may achieve this by influencing the scope of the search and guiding where the firm pays attention when seeking complementary knowledge that the firm particularly needs (Tihanyi, Ellstrand, Daily, \& Dalton, 2000). Also, managerial experience may minimise cultural barriers to establishing network-based relationships, and is associated with the ability to reinforce preexisting business or political ties (Lyles et al., 2014). This is particularly crucial as EMNEs often suffer from a lack of social legitimacy in advanced countries. Ultimately, knowledge about local institutions and businesses resides at the individual level. Knowing whom to interact with, whether the knowledge sought can be separated from unneeded parts of the acquiree, and where to hire scientists and engineers affect greatly the viability of knowledge-seeking FDI (Hennart, 2012). Following the recent studies, we measure TMT experience by the percentage of TMT members who have working and managerial experience in the EU (Cui, Li, \& Li, 2013; Cui, Li, Meyer, \& Li, 2015). Data were sourced from annual reports 2009-2011. Given the short internationalization history of Chinese firms, our sample shows the maximum percentage of TMT members who have local experience is $33 \%$, and a mean value of $4 \%$. For some firms, there is no TMT member who has worked in the EU. We calibrated $10 \%$ in any company as full membership, which is at about the 20th percentile, while $0 \%$ (none of the TMT members) was naturally set as the threshold for full non-membership. The crossover point was set at $5 \%$, which is an average value between fully-in and fully-out membership and slightly higher than the mean value.

\section{Leverage conditions}

We identify three leverage conditions. Provincial institutional development determines the institutional compatibility between the home and host locations. Financial slack indicates the firm's financial resources. Absorptive capacity is associated with the firm's technological capabilities. All are rooted in the resource- and capability-based paradigm, but are expected to work in complement with the linkage conditions.

Provincial institutional development A firm's strategy and behaviour are conditioned by the immediate institutional environment in which it operates (Peng, Wang, \& Jiang, 2008). Emerging countries with diverse geographic and administrative regions are likely to see varying degrees of institutional development at the sub-national level. Specifically, China's administrative decentralisation has granted provincial governments substantial discretion in making and enforcing economic policies, with particular regard to the regulation of product market, factor market and resource allocation (Boisot \& Meyer, 2008). Localised formal rules, divergent enforcement of nationwide policies and local government protectionism all give rise to persistent subnational variations in market-supporting institutions in terms of economic liberalisation, property rights protection and effectiveness of legal systems (Chen, Li, \& Shapiro, 2015). In regions where market-supporting institutions are well-developed, firms compete on their technological and marketing capacity to serve the market. Economic liberalisation welcomes persistent entry of foreign investors into these regions and this imposes pressure on domestic firms to engage in exploratory and experiential learning (Hitt, Li, \& Worthington, 2005). Gradual pro-market reform allows local latecomers to model on 
foreign investors, learn to play by capitalist rules, and emulate incumbents on technology, management practices and international standards (Guthrie, 2005). An effective legal system levels the playing field and directs firms' attention away from developing non-market capabilities in search of preferential regulatory treatment. Compared to those from less-marketized regions, Chinese firms growing in developed marketsupporting institutional environments have stronger market-related capabilities and are thus more likely to expand into advanced country markets (Wei, Zheng, Liu, \& $\mathrm{Lu}, 2014)$. This supportive condition may be particularly important for knowledgeseeking FDI. Cantwell (2009) argues that the success of knowledge sourcing depends on the ease of gaining "insider" status in a knowledge centre, which in turn is a function of the institutional compatibility between the home and host locations. Firms that originate from provinces with strong market-support institutions are better positioned to build up trust with local actors in an advanced country and thus tap into technological knowledge embedded in the local production network and innovation system (Cantwell \& Mudambi, 2011). Firms committed to non-market capabilities, such as political connections influenced by home-region institutions (Shi, Markóczy, \& Stan, 2014), are likely to remain "outsiders", which deprives them of the opportunities for knowledge acquisition from and knowledge co-creation with local knowledge holders. Following Gao, Murray, Kotabe, and Lu (2010), we used the province-level index of marketization developed by the National Economic Research Institute (NERI). The yearly NERI index assesses the institutional development of Chinese provinces on five dimensions. We employed principal component analysis to generate a composite score. Following Fiss (2011), we calibrated state ownership by the standard 25th-50th75 th percentile approach. The fully-in membership in the set of provincial institutional development was coded 1 if the value is higher (12.5 and above, i.e., about the 75 th percentile) and was coded 0 if the value is equal or less than 8.05 (about the 25 th percentile). The crossover point was set at $10.5 \%$ (about the 50th percentile).

Financial slack Abundance of financial resources is an important condition favouring EMNEs' catch-up strategies and particularly knowledge-seeking FDI. Given the considerable upfront capital outlays typically associated with the acquisition of foreign strategic assets, and the long lead-time before these assets can yield any return, external financing for knowledge-seeking FDI is usually expensive and difficult to secure (Cui et al., 2014). This problem is more salient to EMNEs because financial markets in most emerging countries are underdeveloped. Financial slack, instead, can be easily deployed when needed (Tan \& Peng, 2003), so that firms can respond quickly as opportunities arise overseas (Garcia-Canal \& Guillén, 2008). EMNEs may accumulate financial slack by two means. First, they may be given privileged access to subsidized capital by the home government (Narula, 2012). Second, they may generate sufficient rents in the home country due to market protectionism and limited competition. Their control of complementary local resources, such as distribution networks, gives them strong bargaining power over foreign entrants, and thus reinforces their ability to capture most of the rents (Hennart, 2012). Readily available free cash flow enables latecomers to purchase the desired parts of an incumbent firm on an equity market (Hennart, 2012). It also facilitates greenfield investments by protecting the EMNE from uncertain outcomes of risk-taking (Nohria \& Gulati, 1996) and environmental changes in international markets (Castrogiovanni, 1991). EMNEs with sufficient financial slack 
are not constrained by immediate performance metrics, and are able to withstand shortterm losses associated with foreign knowledge sourcing (Narula, 2012). We measure financial slack by the current ratio of the investing firm based on Osiris data (Lin, Cheng, \& Liu, 2009). For fuzzy-set calibration, we chose anchor points in line with the International Monetary Fund (IMF) standards for assessing Asian companies (IMF, 2014). Specifically, a current ratio below 1 was considered fully out (absence of sufficient slack), while a current ratio greater than 2 was considered fully in (presence of sufficient slack), with 1.5 as the crossover point.

Absorptive capacity EMNEs' knowledge sourcing in advanced markets is constrained by their own knowledge capital (Li et al., 2012). Researchers are increasingly aware of absorptive capacity as an important precondition for benefiting from spillovers (Cantwell, 2009). Absorptive capacity refers to the ability to identify, absorb and utilize new knowledge from external sources (Zahra \& George, 2002). A large gap in technological knowledge between the source firm and the recipient firm may lower the chance of realizing the potential spillovers. Research suggests that firms take into consideration their capability to benefit from location-specific innovative activity when making location decisions to source knowledge (Alcácer \& Chung, 2007). Meanwhile, through social integration mechanism (such as learned social relationships inside the organization), an organization's absorptive capacity can influence its knowledgeseeking behaviours (Todorova \& Durisin, 2007). While technology laggard firms may be most motivated to seek knowledge, they are also less likely to do so, because the lack of absorptive capacity gives rise to particular difficulty in establishing local connections in foreign knowledge centres and taking advantage of spillovers (Cantwell \& Mudambi, 2011). EMNEs may accumulate absorptive capacity by acquiring mobile knowledge embedded in returnees, products, parts and components, and foreign patent files, or through knowledge transfer from developed-country MNEs in exchange for access to the home market (Hennart, 2012). Absorptive capacity alone cannot sustain innovation capabilities, which require the firm to build a broader knowledge base spanning a variety of technological streams (Awate et al., 2012). However, it enhances the firm's ability to identify complementary innovation and internalise it (Cantwell, 2009).

We measure absorptive capacity using the firm's existing knowledge stock as proxied by cumulative patent counts (Nooteboom, Van Haverbeke, Duysters, Gilsing, \& van den Oord, 2007). We included invention and utility patents, since they are indicative of the firm's awareness of external knowledge capital, competence in assimilating new technological knowledge, and commitment to knowledgegenerating activities. It is generally agreed that the value of knowledge capital depreciates sharply over five years (Ahuja \& Katila, 2001). In gauging a firm's cumulative knowledge stock, we tracked the patent filing date and added up the firm's patent applications to the State Intellectual Property Office of China (SIPO) over the five years prior to the investment year. We then divided this count number by the domestic industry-specific aggregation of patent applications over the same period in order to control for the differential patenting propensity of different industries (Mowery, Oxley, \& Silverman, 1996). Following Fiss (2011), we calibrated absorptive capacity by its data distribution and the percentile approach. Since the mean value is .01, which is only at the 84th percentile, we decided on .01 as the threshold of fully-in membership to 
maintain all fully-in values above the mean; the median (at the 50th percentile) is about .00133 , and we thus treated the crossover point at .001. In corresponding with the fullyin membership, we found that the absorptive capacity ratio has a significant drop to the .0001 level data at about the 14th and 15th percentiles, and therefore we marked .0001 as the threshold of fully-out membership.

\section{Results and propositions}

\section{Configurational solutions and interpretations}

Fs/QCA identifies relationships between the causal conditions that are either necessary or sufficient for a given outcome. We started the analysis by testing whether any of the causal conditions is always related to EMNEs' high learning propensity. The purpose of this step was to identify the presence of any potential necessary conditions that should not be incorporated into the subsequent sufficiency analysis. In fsQCA a condition is considered "necessary", or "almost always necessary", if the condition is required but not necessarily sufficient for an outcome to occur (Ragin, 2008; Schneider et al., 2010). As shown in Table 3, we tested whether any of the six causal conditions is necessary for leading to high learning propensity. The results suggest that none of the individual conditions exceeds the consistency threshold of .90 for necessary conditions (Schneider et al., 2010). Moreover, we also checked the possibility of "substitutable necessary conditions" exceeding the .90 threshold in fsQCA (Ragin, 2006). The consistency measure for "Provincial institutional development + Absorptive capacity" assumes a value of .85 - the highest value among all possible conditions. Therefore, no necessary conditions were identified in the analysis.

Table 4 reports the fuzzy-set sufficiency analysis as to what combinations of linkage and leverage conditions would imply high learning propensities of Chinese MNEs in the EU. The configurational solutions are presented in the generally adopted style (Crilly, 2011; Fiss, 2011; Ragin, 2008); that is, highlighting the parsimonious solutions

Table 3 Necessity analysis

\begin{tabular}{lll}
\hline Causal configuration solutions & \multicolumn{2}{l}{ Chinese MNE's learning propensity in the EU } \\
\cline { 2 - 3 } & Consistency & Coverage \\
\hline Linkage & \multicolumn{2}{c}{} \\
Environmental munificence in the EU & .47 & .51 \\
State ownership & .31 & .49 \\
TMT experience in the EU & .32 & .57 \\
Leverage & .53 & .49 \\
Provincial institutional development & .53 & .48 \\
Financial slack & .56 & .53 \\
Absorptive capacity & & \\
\hline
\end{tabular}

The necessity test is conducted by the fsQCA 2.2 software 
Table 4 Configurational solutions for Chinese MNEs' learning propensity in the EU

\begin{tabular}{|c|c|c|c|c|c|}
\hline \multirow[t]{2}{*}{ Configurations of causal conditions } & \multicolumn{5}{|c|}{ Chinese MNEs' learning propensity in the EU } \\
\hline & Solution 1 & Solution 2 & Solution 3 & Solution 4 & Solution 5 \\
\hline \multicolumn{6}{|l|}{ Linkage } \\
\hline Environmental munificence in the EU & $\bullet$ & $\bullet$ & $\otimes$ & $\otimes$ & - \\
\hline State ownership & $\otimes$ & $\otimes$ & - & $\bullet$ & - \\
\hline TMT experience in the EU & $\otimes$ & $\otimes$ & • & $\bullet$ & $\bullet$ \\
\hline \multicolumn{6}{|l|}{ Leverage } \\
\hline Provincial institutional development & $\bullet$ & $\otimes$ & $\otimes$ & $\otimes$ & $\bullet$ \\
\hline Financial slack & $\otimes$ & $\bullet$ & - & $\otimes$ & $\otimes$ \\
\hline Absorptive capacity & $\bullet$ & $\otimes$ & $\otimes$ & - & $\otimes$ \\
\hline Consistency & .91 & .89 & .91 & .90 & .95 \\
\hline Raw coverage & .08 & .09 & .08 & .08 & .08 \\
\hline Unique coverage & .04 & .06 & .01 & .02 & .04 \\
\hline Representative case & EGing & Leking & Goldwind & Weichai & HT-SAAE \\
\hline Overall solution consistency & .92 & & & & \\
\hline Overall solution coverage & .25 & & & & \\
\hline
\end{tabular}

Black circles indicate the presence of a condition, and circles with " $\mathrm{X}$ " indicate its absence. Large circles indicate core conditions, and small ones peripheral conditions. Blank spaces indicate "don't care"

(Crilly, 2011) based on the intermediate solution (Ragin, 2008). With regard to the notation, black circles $(\bullet)$ indicate the presence of a condition, and circled crosses $(\otimes)$ indicate its absence. Large circles indicate core conditions (that is, highlighting parsimonious solutions), while small ones are peripheral conditions. The core-periphery distinction is based on the depth and significance of the casual conditions, in that those marked as "core" represent a "must", while "peripheral" conditions play a contributing role (Fiss, 2011). Blank spaces indicate ambiguous situations in which the corresponding causal condition may be either present or absent, and therefore it plays an insignificant role in the configurational solution. Grouped by their core conditions, Table 4 shows that fuzzy-set analysis results in five major solutions, each representing a configuration of linkage and leverage conditions as a causal pathway toward strong learning propensity of Chinese MNEs in the EU. Below we develop propositions based on the specific configurations.

\section{Proposition development}

A closer look at the configurational solutions suggests that all involve at least one linkage condition and one leverage condition. This lends clear support to LLL's proposition regarding the interrelationship between linkage, leverage and learning. It is the right combinations of linkage and leverage that allow for knowledge sourcing and acquisition at foreign knowledge centres where agglomeration economies and spillovers confer concrete access to cutting-edge technologies. LLL describes the capability upgrading process as an upward spiral in the sense that prior learning points to the 
firms' weaknesses and establishes new linkages, and leverages are accumulated to rectify the deficiency (Mathews, 2006). In this spirit, we develop the propositions by discussing what leverages are needed under certain linkage conditions to trigger strong learning propensities of EMNEs.

\section{When the environment helps}

A munificent environment provides an important linkage condition for EMNEs' knowledge sourcing. When industrial resources are abundant in the host region, all actors along the supply chain can pursue goals other than survival. For instance, local firms may welcome foreign rivals with complementary resources to come to engage in value co-creation. When the entire market capacity keeps expanding, new players emerge constantly to take advantage of the market growth. Existing suppliers and customers are also less likely to be contractually tied to the incumbent manufacturer for the long term. Employee mobility tends to be greater as new players and aspiring incumbents long for experienced scientists and engineers with competitive offers. This creates ample room for outsiders to break into the existing production network and tap into knowledge spillovers.

While the industrial environment provides natural access to technological knowledge for latecomers, not all of them are poised to seize the opportunities. They need to possess the right leverage resources. Our results identify two viable but distinct types of firms. First, the firms should originate from a home institutional environment compatible with that in an advanced economy and have accumulated some technological knowledge (Solution 1). These two conditions might be interrelated. In institutionally developed regions, economic liberalisation, strong property rights protection and an effective legal system determine that firms compete with one another in market-related capabilities, including technological capability (Sun, Peng, Lee, \& Tan, 2015). The resulting absorptive capacity - from acquiring mobile knowledge embedded in products and foreign patent files, or from knowledge transfer over the process of inward internationalisation (Hennart, 2012) - does not automatically lead to innovation capabilities, but more to output capabilities, i.e. producing the latest product efficiently (Awate et al., 2012). Nevertheless, absorptive capacity (technological knowledge) guides the firm in searching for a broad range of complementary knowledge available in advanced markets in order to develop the next generation of the product (Cui, Fan, $\mathrm{Liu}, \& \mathrm{Li}, 2017)$. Technology searching is empowered by embedding the firm in local business networks. While the munificent environment makes this easier for latecomers from emerging countries, we find compatible institutions between home and host locations also crucial as they help secure an insider status for the latecomer in local networks (Cantwell, 2009).

Second, the firms should possess sufficient financial resources (Solution 2). In fact, our findings point out that financial slack substitutes for the combination of institutional compatibility and absorptive capacity. For those firms wanting to catch up with established MNEs but losing out on basic technological capability, partly due to their location of origin, tapping into knowledge centres in advanced countries may be an accelerated route. When the growing host market welcomes new entrants, cash-rich latecomers can strike better deals with the extant suppliers and customers and access their knowledge capital by means of business cooperation and social exchange. Cash- 
rich firms may hire experienced scientists and engineers from foreign and local rivals by offering more attractive compensation packages. In addition, cash-rich firms are less concerned about acquisition premium and can purchase the desired knowledge holder outright. This is not only the fastest route to knowledge acquisition for latecomers, but also particularly appealing to advanced country firms hit badly by the financial crisis.

Proposition 1a When the industrial environment is munificent for latecomer EMNEs, home-host institutional compatibility alongside adequate absorptive capacity will lead to high learning propensity.

Proposition 1b When the industrial environment is munificent for latecomer EMNEs, possessing adequate financial resources will lead to high learning propensity.

\section{When the environment does not help}

When the host region industry is less munificent, this raises intrinsic difficulty for latecomers from outside in accessing knowledge stock. Sluggish growth of market capacity and demand leads to intense competition among the incumbents for consumers. Survival is the priority goal, and cooperation between rivals becomes less likely. In a stable or even declining industry, new players are deterred or blocked. Most suppliers and customers tend to be either contractually tied with the manufacturers or owned by them. To compensate, latecomers from emerging countries must find other ways to link with the local production networks or establish new value chains. We find that EMNEs can utilise political channels supported by the state and capitalise on TMT members' experience in the host region. The home country government may bolster domestic industrial catch-up by introducing SOEs to local political and business leaders during high-level visits to foreign knowledge centres. This helps SOEs gain political legitimacy in the eyes of the dominant players in the industry, and secure high-profile deals with them (Li, Meyer, Zhang, \& Ding, 2017). Recognition may then spread across other knowledge holders. Nevertheless, our findings suggest that state support is not enough and needs to be accompanied by locally experienced TMT, because of a weak legitimacy of SOEs in countries where state ownership is not a common governance structure (Meyer et al., 2014). Despite support from the upper echelons of both home and host governments, concerns could still arise regarding perceived threats to local industry and unfair competitive advantage due to ideological conflicts. Experienced TMT members are familiar with the local normative and coercive institutions and their way of doing business. By actively engaging with the dominant industrial players, the TMT guides the firm in sourcing relevant knowledge and also enhances the firm's social legitimacy in host communities.

Under these linkage conditions, we find that EMNEs need to leverage either financial resources (Solution 3) or technological absorptive capacity (Solution 4) to take advantage of the benefits of spillovers. Again, this implies that cash-rich firms and technologically knowledgeable firms may represent two different types of latecomers. Cashrich firms without a strong capacity to identify and assimilate new knowledge may pursue an accelerated route toward catch-up by supplying capital to foreign knowledge holders - a much-needed resource in an era of economic recession. This is a particularly 
effective strategy for Chinese SOEs, who operate under soft budgets supported by stateowned banks (Luo et al., 2010). Conversely, firms with strong absorptive capacity may be those seeking to move up the value chain. They do so by sourcing complementary knowledge from a variety of fields of expertise in advanced countries that can be combined with their own knowledge base and contribute to the development of new product and sustainable innovation capabilities (Awate et al., 2012).

It should be noted in passing that, across all solutions, compatible home institutions are only needed when host region industry is munificent. As the environment becomes inherently less conducive to knowledge spillovers and externalities, gaining an insider status in the existing production networks relies upon political intermediaries and firmspecific facilitators rather than on the firm's institutional imprint, making institutional compatibility less relevant.

Proposition 2a When the industrial environment is less munificent for latecomer EMNEs, linkages through political channels and locally experienced TMT members, alongside adequate financial resources, will lead to high learning propensity.

Proposition 2b When the industrial environment is less munificent for latecomer EMNEs, linkages through political channels and locally experienced TMT members, alongside adequate absorptive capacity, will lead to high learning propensity.

\section{When strong linkages are present}

Our findings also identify a solution where the firm enjoys strong linkage conditions (Solution 5). The host task environment is conducive to new entrants, while the firm also benefits from state support and a locally experienced TMT. In this case, the firm can break into the localised production network with relative ease, identify and approach the right knowledge holder, and build up legitimacy in the eyes of the dominant industrial players. While one might envisage that the leverage condition is no longer needed, the configurational solution again lends support to the basic proposition of the LLL framework. We find that, even under such facilitating conditions for establishing outward linkages, the latecomer still needs to leverage the institutional compatibility between home and host locations. It is worth noting that market-supporting institutions in the home region do not necessarily help firms accumulate financial resources or technological capabilities useful for knowledgeseeking FDI. Nor does our result imply that this group of firms have no resources at all. Domestic firms' learning is myopic, in that they cannot anticipate the strategic significance of the resources acquired from experiential learning at the time they are acquired (Barney, 1986). Resources acquired for one purpose - for instance, to achieve efficient production may prove valuable in subsequent knowledge sourcing from role models in an advanced market (Mathews, 2002). What seems to matter more for this group of firms is sharing the common ground with the incumbents. EMNEs emanating from institutionally developed home regions have been aligned with capitalist rules, free market competition and contemporary management practices, and thus they face less liability of foreignness and outsidership arising from institutional differences. Common coercive understanding of corporate communication and corporate governance helps latecomers maximize the benefits from these linkage conditions. Interestingly, while all the other solutions suggest that firms' 
strong learning propensities are enabled by either sufficient financial resources or some degree of technological capabilities, we find that sufficiently favourable linkage conditions can substitute for these conventional prerequisites and allow latecomers to engage in foreign knowledge sourcing even in the absence of firm-specific assets.

Proposition 3 When linkage conditions are sufficiently favourable for latecomer EMNEs, home-host institutional compatibility will lead to high learning propensity.

\section{Robustness test}

We performed various robustness checks to evaluate the stability of the configurational solutions. Two common approaches were applied. Following Crilly (2011), we checked the robustness of our results by reducing the threshold used in the fsQCA procedure. For the relatively large sample used for fsQCA $(N>50)$, achieving .80 is already a robust result (cf. Fiss, 2011; Schneider et al., 2010). As shown in Table 4, there is a clear gap between the current consistency cutoff, .89, and the next value, .73 , in the consistency column, which is less than a recommended reduced consistency threshold of .75 for robustness test (Crilly, 2011; Ragin, 2008). Therefore, we opted to further reduce the consistency threshold to .70 . Solutions 1 to 5 remain within the robustness test range for the learning propensity solutions. The overall solution consistencies are considerably lower than those reported in Table 4 (.74 for the learning propensity solutions), although the coverage scores increase (.44 for the learning propensity solutions). While he number of the configurations also increased (seven intermediate solutions), they became less precise, as one would expect when applying a lower consistency threshold (Crilly, 2011).

Given the 25th-50th-75th percentile approach applied to the majority of causal conditions and the outcome in our calibration, we also conducted another robustness check following Campbell et al. (2016) in order to test the extent to which our analysis is sensitive to the specification of calibration rules. We adjusted the upper and lower thresholds by using the 70th percentile as "fully in" and of the 30th percentile as "fully out" for learning propensity, provincial institutional development, environment munificence, and absorptive capacity. Our new results remain substantively unchanged and generate five identical solutions, but the overall consistency decreases to .90 and the overall coverage is still .25. Therefore, our robustness checks confirm that the configurational solutions are stable and our original threshold is preferred.

\section{Discussion}

In this paper, we draw on the LLL framework and knowledge seeking literature to address the question of what allows EMNEs to catch up with the incumbent firms and, particularly, to source knowledge in advanced countries. As suggested by Delbridge and Fiss (2013), the idiom-categorization of social phenomenon is a crucial approach to explaining and understanding the integration of distinctive social constructs and the meanings of their interactions. Our study follows the set-theoretic approach and QCA technique to identify distinct characteristics of different types of Chinese MNEs all showing great propensities 
to learn in the EU. Below we discuss the implications of our analysis for the burgeoning EMNE literature, and how the configurational understanding can complement conventional theories resting on the contingency approach to guide future research.

As one of the prominent alternative theories of the EMNE (Peng, 2012), LLL departs from resource-based paradigm by shedding light on how firms create rather than sustain ownership advantages (Mathews, 2002). LLL seems to be viewed as providing a generic strategy for any latecomers or "infant MNEs" who seek to catch up in an accelerated fashion, while ownership advantages - the well-received necessary condition of foreign expansion - are not required ex ante (Narula, 2012; Tan \& Mathews, 2015). The absence of this time-tested prerequisite has led to a crucial criticism of LLL that it says little about why EMNEs can compete with incumbent firms in foreign territories whilst sourcing knowledge (Hennart, 2012; Ramamurti, 2012). Arguably, the question cannot be addressed on the grounds of home countrybased motivations, such as institutional escapism (Luo \& Wang, 2012), or distinctive home country-based advantages such as political capabilities, which are mostly applicable to other emerging markets (Cuervo-Cazurra, 2012). We echo Hennart's (2012) argument that market imperfections in the home country give emerging country firms sufficient ability to generate and appropriate rents which then finance their knowledgeseeking FDI, making superior intangibles unnecessary for foreign expansion.

In our view, an important fact yet to be fully accounted for is that some latecomers are better positioned to implement catch-up or asset-augmenting strategies than others. Our study shows that this gap in the literature can be resolved within the LLL framework, but it requires an extension from the process of resource leverage and knowledge acquisition toward its preconditions. Building on the knowledge seeking literature, our analysis is predicated on the premise that firms pursuing knowledgeseeking FDI prefer locations with greater knowledge-generating activities and knowledge stock (Alcácer \& Chung, 2007; Li et al., 2012). These locations provide ample opportunities for latecomers to acquire cutting-edge technological knowledge which can compensate for their ownership disadvantages and pave the way for the most accelerated route to catch-up. We believe that explaining why only certain EMNEs engage in knowledge-seeking FDI by reference to their linkage and leverage conditions makes a unique contribution to the theory of emerging country FDI.

While our findings lend support to the baseline contention of LLL, new insights accrue from extending the original realm of inquiry. LLL views capability upgrading as preceding international expansion, given Mathews' considerable discussion about learning opportunities embedded in inward internationalisation and OEM contracting (Mathews, 2002). Emphasis has been placed on how the strategic shift on the part of incumbents creates linkage opportunities unprecedented in the pre-globalisation era. That EMNEs' productive capacity fits well the incumbents' outsourcing strategies undoubtedly facilitates the development of linkages and complementary resources. Yet this is not necessarily the only route by which EMNEs can catch up quickly in the global market. The explanation of EMNEs' engagement in advanced markets should not be solely based on the linkages that are already there (Luo \& Tung, 2007). Latecomers not only just happen to be inserted into the interconnected production network from the home country, but also proactively look out for and seize opportunities overseas to redress resource inadequacy ( $\mathrm{Li}, 2007)$. Each iterative round of linking and leveraging helps EMNEs access new resources of increasing sophistication, and thus deepens their technological capabilities and managerial 
competence (Mathews, 2006). Under the LLL framework, firms have discretion in the strategic choices over the forms of linkage and the resources to be leveraged, and may sit in different spots along this upward spiral of capability upgrading. For some EMNEs, FDI is a sign of successful initial learning about how to apply knowledge in a foreign territory in pursuit of further learning, while for others learning is the intrinsic goal behind the act of FDI (Deng, 2009; Li, 2007; Rui \& Yip, 2008). The difference between the two approaches is that, in the former case, learning may start with a myopic, local search inspired by the inward partnership with foreign incumbents, while in the latter case EMNEs' choices are deliberate and the efforts systematic (Luo \& Tung, 2007). By revealing the preconditions for knowledge-seeking FDI, we extend the LLL framework from local learning to foreign knowledge sourcing, which, as suggested by the knowledge seeking literature, is a more general and strategic route toward catch-up (Chung \& Yeaple, 2008; Li et al., 2012).

Our analysis speaks directly to the Chinese and EU contexts. Much of the recent research on EMNEs' and particularly Chinese MNEs' foreign expansion falls under the rubric of LLL to provide a learning-based explanation of internationalisation (Peng, 2012; Yiu, 2011). The lack of market liberalisation may have made local learning particularly difficult for Chinese firms, which are tempted to tap knowledge centres in advanced countries. This has led to various typologies of Chinese MNEs on the basis of their evolutionary trajectories, investment motivations and resource bases (e.g., Luo \& Tung, 2007). By contrast, our equifinality approach provides a novel yet timely description of the characteristics of Chinese knowledge seekers based on structured set-theoretic classification. Considerable heterogeneity exists within the general category of Chinese latecomers as various combinations of linkage and leverage conditions can lead to knowledge-seeking FDI.

While it is tempting to call on Chinese firms to improve on network ties and capability-upgrading prior to foreign knowledge acquisition, we find that none of the enabling conditions is necessarily helpful independently; nor is it always needed in a configurational solution. There is no "one-size-fits-all" kind of role model for Chinese latecomers. Multiple pathways are feasible for acquiring technological knowledge in foreign knowledge centres. Only the fit between selected linkage and leverage conditions sufficiently prompts firms' knowledge sourcing in advanced markets. This has implications for those aspiring to move up the value chains, as well as the home government craving for domestic industrial catch-up.

On the other hand, we capitalise on the distinctiveness of the EU context. Our premise regarding knowledge-seeking location strategy may be particularly viable in the EU, characterised by the diversity of economic development and knowledge stock across its member states. The EU single market and low factor costs in some of the member states, such as Romania and Czech Republic, suggest that only those seeking to benefit from knowledge spillovers would enter countries with greater knowledge stock that offsets the costly operations. Given the EU's leading position in knowledge-intensive manufacturing, it is not unreasonable to expect an upward trend of entries by Chinese latecomers in years to come. Our analysis provides the EU regulators with a more nuanced view of the characteristics of current knowledge seekers. Of particular note is that cash-rich firms and technologically knowledgeable firms represent two distinct groups of latecomers from China. Although both seek to access knowledge in the EU, they may contribute different complementary resources and have different implications for the local economy. Our analysis will help EU regulators engage better with the influx of Chinese capital. 


\section{Limitations and future research}

We suggest future research to address limitations of the current study. First, our outcomelearning propensity - does not directly measure learning per se. Higher learning propensity only explains why EMNEs exist but not necessarily why they can rise to compete against established firms in a sustainable fashion. It may well be possible that favourable linkage and leverage conditions allowing for knowledge sourcing have diminished before the firm manages to absorb new knowledge and upgrade the resource base successfully. To sustain competitive advantage globally, knowledge sourcing needs to be combined with strong capabilities of identifying and internalising the right knowledge for product and service innovation (Awate et al., 2012). That said, our study provides fresh and important insights into the preconditions of learning. For any given EMNE, a great learning propensity alone does not pave the way for the competitive foundation for long-run success. Without it, however, any catch-up would remain wishful thinking rather than a real prospect.

Second, another dimension of learning that merits further investigation is the process of learning. Both LLL and springboard perspective discuss in theory the recurrent, iterative nature of knowledge sourcing and capability upgrading. Empirical studies, including ours, are yet to provide definitive evidence on how MNEs can effectively apply acquired knowledge to facilitate subsequent learning. This may require longitudinal and in-depth case studies over an extended time period (Lyles et al., 2014).

Third, at early stages of internationalization, most Chinese firms established their subsidiaries in the EU with multiple purposes. A subsidiary may assume the role of sales and knowledge acquisition concurrently, as noted in our data. Future research may collect primary data to ascertain the subsidiary's mandate and verify the validity of our propositions. Moreover, specific learning purposes of knowledge-seeking FDI (e.g., marketing, $\mathrm{R} \& \mathrm{D}$, and/or manufacturing knowledge) may be tied to the main function of EMNE's foreign subsidiaries. Knowledge acquisition may be facilitated when there is a clear match between the parent firm's learning purpose and the subsidiary's main function. We suggest future research to further explore the nuances of foreign knowledge sourcing.

Lastly, our mid-range theory building is based on a small sample of Chinese listed MNEs and a particular host context that may raise concerns about external validity. Because of data limitation, we could not include unlisted Chinese firms' FDIs in EU, which may cause sample selection bias for our study. Besides, although Chinese investment in the EU represents a notable case of the emergence of EMNEs and has been put under spotlight by the media, whether our findings and propositions can contribute to the wider phenomenon is, after all, subject to future investigations using large $\mathrm{N}$ samples and focusing on EMNEs from multiple emerging countries.

Open Access This article is distributed under the terms of the Creative Commons Attribution 4.0 International License (http://creativecommons.org/licenses/by/4.0/), which permits unrestricted use, distribution, and reproduction in any medium, provided you give appropriate credit to the original author(s) and the source, provide a link to the Creative Commons license, and indicate if changes were made.

\section{References}

Ahuja, G., \& Katila, R. 2001. Technological acquisitions and the innovation performance of acquiring firms: A longitudinal study. Strategic Management Journal, 22(3): 197-220. 
Alcácer, J., \& Chung, W. 2007. Location strategies and knowledge spillovers. Management Science, 53(5): $760-776$

Andersson, U., \& Forsgren, M. 2000. In search of Centre of excellence: Network embeddedness and subsidiary roles in multinational corporations. Management International Review, 40(4): 329-350.

Awate, S., Larsen, M. M., \& Mudambi, R. 2012. EMNE catch-up strategies in the wind turbine industry: Is there a trade-off between output and innovation capabilities? Global Strategy Journal, 2(3): 205-223.

Barney, J. 1986. Strategic factor markets: Expectations, luck, and business strategy. Management Science, 32(10): 1231-1241.

Boisot, M., \& Meyer, M. W. 2008. Which way through the open door? Reflections on the internationalization of Chinese firms. Management and Organization Review, 4(3): 349-365.

Brusoni, S., Prencipe, A., \& Pavitt, K. 2001. Knowledge specialization, organizational coupling, and the boundaries of the firm: Why do firms know more than they make? Administrative Science Quarterly, 46(4): 597-621.

Campbell, J. T., Sirmon, D. G., \& Schijven, M. 2016. Fuzzy logic and the market: A configurational approach to investor perceptions of acquisition announcements. Academy of Management Journal, 59(1): 163-187.

Cantwell, J. 2009. Location and the multinational enterprise. Journal of International Business Studies, 40(1): $35-41$.

Cantwell, J., \& Janne, O. 1999. Technological globalisation and innovative centres: The role of corporate technological leadership and locational hierarchy. Research Policy, 28(2): 119-144.

Cantwell, J., \& Mudambi, R. 2005. MNE competence-creating subsidiary mandates. Strategic Management Journal, 26(12): 1109-1128.

Cantwell, J., \& Piscitello, L. 2005. Recent location of foreign-owned research and development activities by large multinational corporations in the European regions: The role of spillovers and externalities. Regional Studies, 39(1): 1-16.

Cantwell, J. A., \& Mudambi, R. 2011. Physical attraction and the geography of knowledge sourcing in multinational enterprises. Global Strategy Journal, 1(3-4): 206-232.

Castrogiovanni, G. J. 1991. Environmental munificence: A theoretical assessment. Academy of Management Review, 16(3): 542-565.

Chen, V. Z., Li, J., \& Shapiro, D. M. 2015. Subnational institutions and outward FDI by Chinese firms: The mediating role of firm-specific advantages. Multinational Business Review, 23(4): 254-276.

Chung, W., \& Alcacer, J. 2002. Knowledge seeking and location choice of foreign direct investment in the United States. Management Science, 48(12): 1534-1554.

Chung, W., \& Yeaple, S. 2008. International knowledge sourcing: Evidence from U.S. firms expanding abroad. Strategic Management Journal, 29(11): 1207-1224.

Crilly, D. 2011. Predicting stakeholder orientation in the multinational enterprise: A mid-range theory. Journal of International Business Studies, 42(5): 694-717.

Cuervo-Cazurra, A. 2012. Extending theory by analyzing developing country multinational companies: Solving the goldilocks debate. Global Strategy Journal, 2(3): 153-167.

Cui, L., Fan, D., Liu, X., \& Li, Y. 2017. Where to seek strategic assets for competitive catch-up? A configurational study of emerging multinational enterprises expanding into foreign strategic factor markets. Organization Studies, 38(8): 1059-1083.

Cui, L., \& Jiang, F. 2012. State ownership effect on firms' FDI ownership decisions under institutional pressure: A study of Chinese outward-investing firms. Journal of International Business Studies, 43(3): $264-284$.

Cui, L., Li, Y., \& Li, Z. 2013. Experiential drivers of foreign direct investment by late-comer Asian firms: The Chinese evidence. Journal of Business Research, 66(12): 2451-2459.

Cui, L., Li, Y., Meyer, K. E., \& Li, Z. 2015. Leadership experience meets ownership structure: Returnee managers and internationalization of emerging economy firms. Management International Review, 55(3): 355-387.

Cui, L., Meyer, K. E., \& Hu, H. W. 2014. What drives firms' intent to seek strategic assets by foreign direct investment? A study of emerging economy firms. Journal of World Business, 49(4): 488-501.

Delbridge, R., \& Fiss, P. C. 2013. Editors' comments: Styles of theorizing and the social organization of knowledge. Academy of Management Review, 38(3): 325-331.

Deng, P. 2009. Why do Chinese firms tend to acquire strategic assets in international expansion? Journal of World Business, 44(1): 74-84.

Dess, G. G., \& Beard, D. W. 1984. Dimensions of organizational task environments. Administrative Science Quarterly, 29(1): 52-73.

Dunning, J. H. 2000. The eclectic paradigm as an envelope for economic and business theories of MNE activity. International Business Review, 9(2): 163-190. 
Dunning, J. H., \& Lundan, S. M. 2008. Multinational enterprises and the global economy. Cheltenham: Edward Elgar.

Fernhaber, S. A., \& Patel, P. C. 2012. How do young firms manage product portfolio complexity? The role of absorptive capacity and ambidexterity. Strategic Management Journal, 33(13): 1516-1539.

Fiss, P. C. 2007. A set-theoretic approach to organizational configurations. Academy of Management Review, 32(4): 1180-1198.

Fiss, P. C. 2011. Building better causal theories: A fuzzy set approach to typologies in organization research. Academy of Management Journal, 54(2): 393-420.

Gao, G. Y., Murray, J. Y., Kotabe, M., \& Lu, J. Y. 2010. A "strategy tripod" perspective on export behaviors: Evidence from domestic and foreign firms based in an emerging economy. Journal of International Business Studies, 41(3): 377-396.

Garcia-Canal, E., \& Guillén, M. F. 2008. Risk and the strategy of foreign location choice in regulated industries. Strategic Management Journal, 29(10): 1097-1115.

Guthrie, D. 2005. Organizational learning and productivity: State structure and foreign investment in the rise of the Chinese corporation. Management and Organization Review, 1(2): 165-195.

Hashai, N., \& Buckley, P. J. 2014. Is competitive advantage a necessary condition for the emergence of the multinational enterprise? Global Strategy Journal, 4(1): 35-48.

Hennart, J.-F. 2012. Emerging market multinationals and the theory of the multinational enterprise. Global Strategy Journal, 2(3): 168-187.

Hitt, M. A., Li, H., \& Worthington, W. J. 2005. Emerging markets as learning laboratories: Learning behaviors of local firms and foreign entrants in different institutional contexts. Management and Organization Review, 1(3): 353-380.

IMF 2014. Corporate leverage in Asia: A fault line? Washington, DC:International Monetary Fund.

Jaffe, A. B., Trajtenberg, M., \& Henderson, R. 1993. Geographic localization of knowledge spillovers as evidenced by patent citations. Quarterly Journal of Economics, 108(3): 577-598.

Jindra, B., Hassan, S. S., \& Cantner, U. 2016. What does location choice reveal about knowledge-seeking strategies of emerging market multinationals in the EU? International Business Review, 25(1, Part A): 204-220.

Judge, W. Q., Fainshmidt, S., \& Brown, J. L. I. 2014. Which model of capitalism best delivers both wealth and equality? Journal of International Business Studies, 45(4): 363-386.

Keats, B. W., \& Hitt, M. A. 1988. A causal model of linkages among environmental dimensions, macro organizational characteristics, and performance. Academy of Management Journal, 31(3): 570-598.

Kedia, B., Gaffney, N., \& Clampit, J. 2012. EMNEs and knowledge-seeking FDI. Management International Review, 52(2): 155-173.

Kinne, B. J. 2014. Dependent diplomacy: Signaling, strategy, and prestige in the diplomatic network. International Studies Quarterly, 58(2): 247-259.

Kogut, B., \& Zander, U. 1992. Knowledge of the firm, combinative capabilities, and the replication of technology. Organization Science, 3(3): 383-397.

Kogut, B., \& Zander, U. 1993. Knowledge of the firm and the evolutionary theory of the multinational corporation. Journal of International Business Studies, 24(4): 625-645.

Li, J., Li, Y., \& Shapiro, D. 2012. Knowledge seeking and outward FDI of emerging market firms: The moderating effect of inward FDI. Global Strategy Journal, 2(4): 277-295.

Li, J., Meyer, K. E., Zhang, H., \& Ding, Y. 2017. Diplomatic and corporate networks: Bridges to foreign locations. Journal of International Business Studies, 49(6): 659-683.

Li, P. P. 2007. Toward an integrated theory of multinational evolution: The evidence of Chinese multinational enterprises as latecomers. Journal of International Management, 13(3): 296-318.

Lin, W.-T., Cheng, K.-Y., \& Liu, Y. 2009. Organizational slack and firm's internationalization: A longitudinal study of high-technology firms. Journal of World Business, 44(4): 397-406.

Luo, Y., \& Tung, R. L. 2007. International expansion of emerging market enterprises: A springboard perspective. Journal of International Business Studies, 38(4): 481-498.

Luo, Y., \& Wang, S. L. 2012. Foreign direct investment strategies by developing country multinationals: A diagnostic model for home country effects. Global Strategy Journal, 2(3): 244-261.

Luo, Y., Xue, Q., \& Han, B. 2010. How emerging market governments promote outward FDI: Experience from China. Journal of World Business, 45(1): 68-79.

Lyles, M., Li, D., \& Yan, H. 2014. Chinese outward foreign direct investment performance: The role of learning. Management and Organization Review, 10(3): 411-437.

Mathews, J. A. 2002. Competitive advantages of the latecomer firm: A resource-based account of industrial catch-up strategies. Asia Pacific Journal of Management, 19(4): 467-488. 
Mathews, J. A. 2006. Dragon multinationals: New players in 21st century globalization. Asia Pacific Journal of Management, 23(1): 5-27.

Meyer, K. E., Ding, Y., Li, J., \& Zhang, H. 2014. Overcoming distrust: How state-owned enterprises adapt their foreign entries to institutional pressures abroad. Journal of International Business Studies, 45(8): 1005-1028.

Mowery, D. C., Oxley, J. E., \& Silverman, B. S. 1996. Strategic alliances and interfirm knowledge transfer. Strategic Management Journal, 17(S2): 77-91.

Narula, R. 2012. Do we need different frameworks to explain infant MNEs from developing countries? Global Strategy Journal, 2(3): 188-204.

Nohria, N., \& Gulati, R. 1996. Is slack good or bad for innovation? Academy of Management Journal, 39(5): $1245-1264$.

Nooteboom, B., Van Haverbeke, W., Duysters, G., Gilsing, V., \& van den Oord, A. 2007. Optimal cognitive distance and absorptive capacity. Research Policy, 36(7): 1016-1034.

Peng, M. W. 2012. The global strategy of emerging multinationals from China. Global Strategy Journal, 2(2): 97-107.

Peng, M. W., Wang, D. Y. L., \& Jiang, Y. 2008. An institution-based view of international business strategy: A focus on emerging economies. Journal of International Business Studies, 39(5): 920-936.

Ragin, C. C. 2006. Set relations in social research: Evaluating their consistency and coverage. Political Analysis, 14(3): 291-310.

Ragin, C. C. 2008. Redesigning social inquiry: Fuzzy sets and beyond. Chicago:University of Chicago Press.

Ramamurti, R. 2012. What is really different about emerging market multinationals? Global Strategy Journal, 2(1): 41-47.

Ray, P. K., Ray, S., \& Kumar, V. 2017. Internationalization of latecomer firms from emerging economiesThe role of resultant and autonomous learning. Asia Pacific Journal of Management, 34(4): 851-873.

Rugman, A. M. 2009. Theoretical aspects of MNEs from emerging economies. In R. Ramamurti, \& J. V. Singh (Eds.). Emerging multinationals in emerging markets. New York: Cambridge University Press.

Rui, H., \& Yip, G. S. 2008. Foreign acquisitions by Chinese firms: A strategic intent perspective. Journal of World Business, 43(2): 213-226.

Sambharya, R. B. 1996. Foreign experience of top management teams and international diversification strategies of U.S. multinational corporations. Strategic Management Journal, 17(9): 739-746.

Schneider, M. R., Schulze-Bentrop, C., \& Paunescu, M. 2010. Mapping the institutional capital of high-tech firms: A fuzzy-set analysis of capitalist variety and export performance. Journal of International Business Studies, 41(2): 246-266.

Shi, W., Markóczy, L., \& Stan, C. V. 2014. The continuing importance of political ties in China. Academy of Management Perspectives, 28(1): 57-75.

Sun, S. L., Peng, M. W., Lee, R. P., \& Tan, W. 2015. Institutional open access at home and outward internationalization. Journal of World Business, 50(1): 234-246.

Tan, H., \& Mathews, J. A. 2015. Accelerated internationalization and resource leverage strategizing: The case of Chinese wind turbine manufacturers. Journal of World Business, 50(3): 417-427.

Tan, J., \& Peng, M. W. 2003. Organizational slack and firm performance during economic transitions: Two studies from an emerging economy. Strategic Management Journal, 24(13): 1249-1263.

Tian, X. 2017. Learning breakdown in latecomer multinational enterprises. Asia Pacific Journal of Management, 34(4): 823-850.

Tihanyi, L., Ellstrand, A. E., Daily, C. M., \& Dalton, D. R. 2000. Composition of the top management team and firm international diversification. Journal of Management, 26(6): 1157-1177.

Todorova, G., \& Durisin, B. 2007. Absorptive capacity: Valuing a reconceptualization. Academy of Management Review, 32(3): 774-786.

Wang, C., Hong, J., Kafouros, M., \& Wright, M. 2012. Exploring the role of government involvement in outward FDI from emerging economies. Journal of International Business Studies, 43(7): 655-676.

Wei, Y., Zheng, N., Liu, X., \& Lu, J. 2014. Expanding to outward foreign direct investment or not? A multidimensional analysis of entry mode transformation of Chinese private exporting firms. International Business Review, 23(2): 356-370.

Yiu, D. W. 2011. Multinational advantages of Chinese business groups: A theoretical exploration. Management and Organization Review, 7(2): 249-277.

Zahra, S. A., \& George, G. 2002. Absorptive capacity: A review, reconceptualization, and extension. Academy of Management Review, 27(2): 185-203. 